\title{
Leveraging Resources for Growth
}

\section{Different Strategies for Growth}

Specific managerial practices adopted by the SMEs have been detailed in previous chapters. This chapter takes a step back and reviews the growth trajectories of the documented firms over their histories. Plotting growth (expressed in sales) over time (expressed in years) resulted in a scatter diagram that demonstrates substantial differences across the 36 sample firms. If these firms followed the managerial practices described earlier, what then accounted for the substantial differences in size and the speed of growth over the life of the companies? Were there any differences in growth that could be traced to different combinations of the chosen practices?

\section{Differentiation Through Expansion Strategies}

Several types of strategic classification have been used by business strategists in the past. One of the most often used categorizations was put forward more than 60 years ago by Igor Ansoff. ${ }^{1}$ Ansoff's model had companies start from a given combination of technology and products, as well as from a given market, adopting either a strategy of market penetration or, alternatively, moving into new markets with existing technology (market development) or, alternatively, taking new technologies or products but remaining in their existing markets (product development). If a company chose to combine both new markets and new technologies, it was said to pursue a strategy of diversification.

Although developed to guide diversification strategies, the same model can be employed to track general expansion strategies over time. As can be demonstrated, the firms in this sample did not, as a rule, pursue diversification but instead followed

\footnotetext{
${ }^{1}$ Ansoff, I (1957) Strategies for diversification. Harvard Business Review 35/5: 113-124. 
the path of pursuing adjacent opportunities, either in terms of market development or product development. Once a new adjacent market niche was found, companies continued to grow the newly found niche by making it, over time, their existing market by pursuing a market penetration strategy, often leaving behind their initial position held during earlier times.

Typical classic market penetration strategies were followed, among others, by a number of firms.

- Caran d'Ache took a number of different writing instruments and technologies into the same markets.

- Medartis expanded into new Orthopedic applications based upon the same medical or production technology.

- Ricola stayed in the same field but continued to introduce different product versions.

- maxon, once finding its niche in small electric motors, continued to add new versions and improved technology into different markets.

- Bachem increasingly added new products and services aimed at the same markets.

- FISBA continued to innovate in the same optic technology space.

Several companies moved into new markets with their existing technologies, practicing product development. The following companies exemplify this.

- Plumettaz, taking its winding technology into Telecom markets.

- Thermoplan, introduced its cream and milk whipping technology into the commercial espresso market.

- Selectron, extending its electronic controls toward in-train controls.

- Oetiker, expanding its connector technology into new applications and markets.

- Jura, taking its small appliance know-how to in-home espresso machines, which became its major market.

Other companies, once venturing beyond their original core into adjacent fields, experienced a stretch of resources in order to expand along multiple tracks. Those companies often divested some business lines, retrenching to a single line of focus, as was discussed in more detail in Chapter 8/Part IV.

- Filtrox, divesting its equipment and systems business to refocus on filters.

- LEM, divesting its equipment and measurement business to refocus on components.

- Bachem, concentrating on the synthetic peptide area by stepping out of biologically based product lines.

Yet again, reviewing the different versions of market expansion, market penetration, product development, or market development and scattering them out among the 36 companies, no significant differences in growth over time and even longevity 
of firms can be explained, based on these strategy differences. Therefore, other factors still had to account for the differences in growth.

\section{Global Expansion Strategies}

Are these companies, some as small as CHF 25 million in sales, global companies? Are some of the larger, faster-growing firms more global than the smaller ones, growing much more slowly?

In the interviews, the description global was rarely mentioned. As a general rule, the SMEs did not see themselves as global in the traditional sense of the word. Given their moderate size, and their role as exporters, these companies were internationally active, covering many markets, from their home base. The pursuit of global markets was a must for all of them, however, because the domestic market in Switzerland simply did not provide enough opportunity to fund a competitive firm.

Not all global strategies are the same. Global companies are said to follow either a market global or an asset global strategy. ${ }^{2}$ Companies pursuing a strategy to extend sales across multiple geographic markets are described as adopting a market global pathway. Clearly, the researched firms, by the nature of their sales and distribution networks, fit this description. Market global does not require entry into all existing geographic territories, of which there are now more than 200. Instead, market global entails that the majority of the relevant geographic markets for the chosen industry or segment are covered.

A review of the sales and distribution strategies of the smaller researched firms indicates that even those companies maintained distribution, albeit through independent distributors, to as many as 50 or more markets, whereas the larger companies tended to maintain fully owned sales and distribution subsidiaries in their key markets.

- DC Swiss relied on about 30 exclusive distribution and technology partnerships to reach into some 50 international markets.

- Sylvac relied on an extensive global network of independent agents covering most markets with substantial manufacturing industry clusters.

- Jura, about ten times the size of DC Swiss or Sylvac, marketed espresso machines globally through sales subsidiaries in key markets and through national dealerships in other countries.

This experience demonstrates that smaller firms relied mostly on independent dealers or distributors, whereas larger companies had sufficient resources to build international subsidiary networks, exerting greater control over sales.

\footnotetext{
${ }^{2}$ Jeannet JP, Hennessey DH (2004) Global Marketing Strategies (6th edn.). Houghton Mifflin, Boston/New York, p. 259-260.
} 
Larger firms followed an asset global pathway, building production and service assets in key locations to supplement their Swiss base. These companies combined a market global with an asset global pathway to become full-fledged global companies on a relatively small scale-in the range of CHF 200 to CHF 500 million-compared to firms typically viewed as global by international standards, usually accounting for sales in the billions.

- Komax maintained more than a dozen production sites in different countries.

- Oetiker maintained 12 production operations in different countries, accounting for most of its connector output.

- maxon, while marketing to 40 countries, maintained production centers in Germany, Hungary, and Korea.

- Burckhardt Compression expanded production to India, USA, and China.

- Sécheron maintained major production sites in the Czech Republic, China, and Italy.

- LEM operated most of its component operations in China and Bulgaria.

It is interesting to note that these firms exhibited above-average growth and reached higher sales volumes compared to many of the smaller firms. This suggests that the global asset strategy described is closely linked to long-term growth. As shall be pointed out later in this chapter, the ability to field such an extensive global manufacturing footprint is also closely linked to the adoption of other practices in the area of governance, management, and financing, as described, and a willingness to engage in mergers and acquisitions (M\&A), as will be addressed later in this chapter.

What were the underlying forces for these SMEs to adopt such a global posture? A major reason driving them into global markets was, and continues to be, the small domestic market. None of the firms in this research would have been able to prosper to the extent they did if they had restricted themselves to the Swiss market only. Export quotas for most of the firms ranged around 80 percent or more. Although this project was focused on exporting firms, it became clear that none of these firms could exist, or prosper, based on just the local market. Prevailing economies of scale in their chosen sectors demanded a market beyond the home market.

Another important aspect is the reason for the SMEs' global success. These companies selected markets and segments governed by a considerable global logic. ${ }^{3}$ Particularly in B2B markets, industry requirements turning increasingly around the same issues meant that Swiss SMEs could market solutions and products with global appeal. Under those circumstances, moving into multiple markets added to the base volume and rewarded companies that moved into key markets on a global scale.

The globalization of markets, combined with increased market openings and access to more countries for trade, contributed significantly to making these global strategies successful. World trade saw a continued expansion over decades, trade

\footnotetext{
${ }^{3}$ Jeannet JP (2000) Managing with a global mindset. Financial Times/Prentice Hall, London.
} 
barriers were lowered, customs abolished for large regions, such as the EU, and nontrade tariffs were reduced, all contributing to an open market of which these SMEs took advantage. They still had to adopt the practices described in earlier chapters to create superior products, but the economic environment was theirs to exploit.

Reflecting on the most recent developments around the global trade environment, the status of globalization has come under attack from many directions. SMEs grown successful under open world market conditions will need to defend their business in the future under more hostile circumstances. This does not mean that globalization or global strategies are practices of the past. The opportunities of SMEs will remain driven by the global logic of its customer base, requiring the same or similar product solutions based on similar technologies. However, a new approach to harvest those globalized opportunities may be demanded, the outlines of which are slow to emerge.

\section{The Role of M\&A in Growing SMEs}

The number of SMEs in the sample engaging in M\&A activities was relatively small. What does not count here is market expansion, or takeover, of independent distributors, which turns firms into fully owned sales subsidiaries. This process was covered in Chapter 12 on sales and distribution. Highlighted here are the acquisitions of existing players, or businesses, to expand the overall operation and to add either new product lines or strengthen existing ones.

Sefar, the oldest company, was the product of a great merger among several companies in the same business.

- To create Sefar, six firms merged in 1907 to form a single company with two separate business units-Schweiz. Seidengazefabrik AG in Thal (SST) and Schweiz. Seidengazefabrik AG in Zürich (SSZ). Five years later, Züricher Beuteltuchfabrik (ZBF) joined the union. The union dominated the world market for silk bolting cloth. Although established as a single legal entity, SSZ, SST, and ZBF operated independently in the market, presenting themselves independently to take advantage of their respective brands, until merging finally in 1995 by creating Sefar (derived from Seiden-Fabrikanten Réunion, i.e., united silk manufacturers) as a registered limited company. ${ }^{4}$

No other such large merger was recorded for any of the other researched firms. Four companies in particular used the acquisition path successfully by adding additional businesses to their lines: Oetiker Group, Komax, Burckhardt Compression, and Datamars.

\footnotetext{
${ }^{4}$ Adapted from Sefar company profile.
} 
Oetiker, producer of clamps needed by automotive subassemblers, used acquisitions to bring together a set of tools and equipment that could be used for the purpose of assembly of its clamps.

- Oetiker acquired Allert in 1997, active in fastening for the automotive sector, as well as supplying hinged steel belt conveyors. Allert continued to operate under its brand name and was kept as a separate legal entity as a fully owned subsidiary.

- Levi Peterson, a Swedish company active globally in engineered fastening devices specializing in commercial vehicles, was acquired in 2014 and operated as Oetiker Sweden AB, combining sales and production on the same site.

- In 2014, Oetiker acquired Rostra Tool Company, based in Connecticut, USA. Rostra, with a 150-year history, marketed its flagship brand "Sargent Quality Tools," hand tools for crimping, pressing, cutting, and stripping, to wholesale distributors and other industrial users. For Oetiker, the hand tool lines added to Oetiker's system approach serving clients not only with connecting solutions but also provided required installation tools. The company was now operating as Oetiker Tools keeping the Sargent brand name for some products.

- More recently, Oetiker acquired Jiffy-tite in 2016, a leading manufacturer of engineered fluid connection parts, allowing Oetiker to obtain a stronger foothold in the quick connect market segment.

Oetiker maintained reserves for acquisitions and sometimes availed itself of bridge financing. The ability to approach an acquisition target without having to take out credit for the deal added to the credibility as an acquirer. ${ }^{5}$

The Komax strategy to pursue focus in wire processing, for automotive applications in particular, was underpinned by a series of acquisitions that brought in adjacent technologies to enlarge the role Komax played in the automation of wire processing and to integrate these additional steps into an expanded systems offering. ${ }^{6}$

- Starting out with a minority stake in 2011, leading to full ownership in 2015, Komax acquired SLE Quality Engineering $\mathrm{GmbH}$, with a staff of 70 . The German company was a leading supplier of quality control systems for plug-in contact connections and wire harness production, fitting easily into the Komax business.

- Next was the acquisition of TSK, a German company with deep experience in quality assurance in wire assembly. TSK developed and sold testing systems and adaptation units for testing wire harnesses and other electrical/electronic assemblies, as well as components.

- Komax stepped into taping technology in 2016 by acquiring Ondal Tape Processing and Kabatec, the global market leader in the field of taping technology

\footnotetext{
${ }^{5}$ Adapted from Oetiker Group profile.

${ }^{6}$ Adapted from Komax company profile.
} 
systems. Serving primarily the automotive industry, the companies produced both standard and customized equipment and had been collaborating with Komax for several years prior to the acquisition.

- The most recent step into new applications for wire processing was the acquisition of Laselec, a Toulouse, France-based company with a staff of 60 and a subsidiary in the USA. Laselec was a producer of both serial and customized production equipment with a strong business in the aerospace industry. Laselec technology was increasingly applied in the automotive sector also, and through this company Komax expected better access to the aerospace industry, a heavy user of cable and wiring.

- However, when Komax went through an expansionary period in the early 2000s, entering the medical and photovoltaic sectors through a number of acquisitions targeting for new opportunities in the assembly sectors, these forays were disbanded in the process of a reorganization after the impact of the financial crisis of 2008-2009.

All Komax acquisitions were fully integrated into Komax and represented an expansion of the product and service offering aimed at the same customer groups and business.

Other companies using acquisitions to the same customer group, in order to round out their product lines, or enlarge the business, included the following:

- Burckhardt Compression with acquisitions in China and the USA.

- Sécheron with the add-on businesses of Saia and Pixy.

- LNS with acquisitions in the USA and Asia bringing in additional peripheral products to its core bar feeder business.

- Datamars using acquisitions to expand into the farm animal sector with Rumitag of Spain, Temple Tag in the USA and Zee Tag in New Zealand.

- Bachem expanded its business by acquiring related companies with similar product lines through three companies in California (Bachem Inc., Peninsula Laboratories, American Peptide) with related businesses in the UK and a production operation in Switzerland, as well as the Clinalfa brand from a German company.

- Filtrox grew its international business by acquiring several smaller competitors, in the UK, Czech Republic, and Mexico, acquisitions which eventually made Filtrox the number two globally.

These acquisitions succeeded, because they were conducted in the same business, or industry focus, and were integrated into the existing sales channels. For all of these companies, the acquisitions provided significant growth to their business and were made possible through sufficient internal financial resources or access to external investment funds.

Not all acquisitions contracted by the researched firms turned out to be successful. Some, even when in related businesses, did not reach expectations and were later reversed through divestments. 
- LEM expanded beyond its original component transducer business into testing equipment in 1987. An acquisition in the UK in 1989 provided the entry into the instrument market, followed by a takeover of the leading US competitor in 1992, a Swiss supplier in 1993 and an Austrian instruments company in 1995. During this time, profitability of the instruments segment exceeded that of the component business, leading to a forced expansion into the equipment direction.

- With LEM component business picking up substantially as more and more applications were developed, the instruments and equipment business became a drag on LEM results. LEM entered a period of divestment and retrenchment, returning to its core component business. The high current system business was divested through an $\mathrm{MBO}$ in $2003 .^{7}$

Some companies, such as u-blox, have found success with acquiring just elements of operations from other companies, or, as in the case of Bachem, by using only some elements even when acquiring an entire business.

- u-blox operates 15 research and development centers across the world today. Its acquisition strategy was closely linked to the need to gear up development capacity. Starting early in its development, the company concentrated on acquiring engineering teams abroad, avoiding operating businesses and leaving them in their original location. ${ }^{8}$

Although most smaller companies did not engage in acquisitions for expansions, those who did encountered greater challenges than the larger SMEs.

- Kuhn Rikon acquired a 60 percent stake in the company Spring in 1988 giving it an entry into the table-cooking segment and using the company's production capacity. Given a lack of full control, Kuhn Rikon could not impose its ideas when conflicts arose with the minority owners and was eventually forced to sell the stake in the midst of a financing squeeze due to production expansion. In 1999, Kuhn Rikon unsuccessfully sought to acquire Sigg, maker of aluminum drink bottles, ending up with buying some equipment, staff, and brand access. Again, conflicts arose and the Sigg brand had to be relinquished. ${ }^{9}$

- Fraisa, in the midst of a major capital investment in production machinery, acquired Schäublin (ESO) for access to threading tools and gauges. The acquired business was unprofitable, forcing Fraisa to compensate losses through bank loans. After full integration of the operation, the site was later closed as part of a restructuring effort. ${ }^{10}$

\footnotetext{
${ }^{7}$ Adapted from LEM company profile.

${ }^{8}$ Adapted from u-blox company profile.

${ }^{9}$ Adapted from Kuhn Rikon company profile.

${ }^{10}$ Adapted from Fraisa company profile.
} 
- $\mathbf{C + M}$ had made many acquisitions over its history. Over the past 20 years, the company acquired two companies with production sites in La-Chaux-de-Fonds, a dental business, a watch movement company, and a watch case maker, all in the same region. Not all the acquired companies could be kept, and some had to be divested when they did not fit adequately into $\mathrm{C}+\mathrm{M}$ 's global strategy. ${ }^{11}$

In general, companies who made successful acquisitions to their business, and integrated them well, achieved higher growth rates than those companies which did not. As will be pointed out later, a close connection exists with the resourcing of a company that takes advantage of such acquisition opportunities.

\section{Decoding Drivers for Growth by Company Size and Age}

Although information concerning sales, age, and employment was collected on each company, it was never the intent to rank any of the companies by an objective standard, such as size alone. If there was one criterion of interest, it was longevity and uncovering the patterns that led to extended company life. An examination of the chart for growth patterns and firm positions by sales and age yielded two main observations: First, firms either developed primarily in terms of sales growth, even at a relatively young age; or, second, alternatively, they maintained a steady pace over decades while maintaining a moderate size. A few combined both volume growth and steady pace over time.

What then accounted for such differences among these companies? What were the main drivers for sales or volume growth? What was driving the measured pace of smaller firms over long periods of time? What made all of these firms survive over generations?

Two general drivers emerged. First, driving longevity over generations of owners and managers required companies to adhere to the practices described in the earlier chapters, ranging from focus choices, segment choices, smart production footprints, engineering solutions for products, innovation strategies, and, finally, leveraging all the advantages of having a Swiss base. Following those principles ensured relevance in the market and sufficient success in propelling the enterprise forward over many years. It was found that all of the investigated companies had managed to do so, albeit, at times, in different ways.

On the second dimension-sales-another pattern emerged. A noticeable difference in some adopted practices could be discerned for companies above versus those below the CHF 120 million sales limit. The observed differences had to do with the adopted governance, including ownership, management, and financing, as well as the pursued global asset strategy described earlier. However, there turned up another noticeable difference among the firms having reached sales of about CHF 120 million

\footnotetext{
${ }^{11}$ Adapted from $\mathrm{C}+\mathrm{M}$ company profile.
} 
or more, in as much as some of these companies reached significant scale much earlier than others.

\section{Examining Differences in Growth Patterns}

In previous chapters, the outlined management practices provided detailed insights into the kind of decisions that have been made, over time, at the researched firms. In order to detect patterns, practices were bundled with others that were similar; then, each of those was aligned with an individual chapter. The bundles ranged from ownership to governance and market focus, as well as across functional practices, such as marketing, finance, innovation, and production. Since all of the researched firms can be considered successful over an extended period of time, practices were not evaluated in terms of their relative effectiveness nor was their relative effectiveness compared to one another. Coming to the end of this detailed analysis, it is time to see if an assessment is possible that aids in determining which bundles of practices, or combinations thereof, account for most of the differences in growth performance.

A number of questions were posed in this inquiry. In the absence of hard statistics, something deliberately avoided by the authors, pattern analysis was employed to find answers that would help shed some light on the different growth paths observed among the interviewed firms.

To compare different growth patterns, Graphic 23.1 was created, which distributes the companies according to their age in relation to their last known (sometimes only estimated) sales. In this chart, the firms range from about 20 to more than 175 years of age, with those founded more recently shown on the left of the chart and the oldest clustered on the right. At first glance, one can spot the youngest firm (Wyon, 1999) in the bottom left corner and the oldest (Sefar, 1833) in the upper right quadrant. Superficially, this might suggest the conclusion that as firms grow older, their size increase-not an earth-shattering conclusion onto itself! Yet, simply looking at years of operation would not lead to significant insights. When viewed from the perspective of sales, or size - in this case taking all the firms above CHF 120 million in sales into consideration-the chart demonstrates that this segment includes companies of varying ages, ranging from u-blox (1997) to Sefar (1833); this indicates that among the larger firms there were both those which had been founded recently and some that have been operating for a long time.

Equally, clustering companies that had sales below CHF 120 million included among the more recently founded firms Medartis (1997) and Wyon (1999), as well as long-running companies, such as Kuhn Rikon (1925) or Lantal (1886). Again, simply relying on years of operation would not lead to sufficiently deep insights regarding the reasons for the varied growth patterns.

Even more telling were vertical patterns, clustering the companies by age, as expressed in decades. The 20-year vertical included firms as small as Wyon, with estimated sales of less than 20 million, as well as u-blox with sales of more than CHF 400 million. The same distribution from small (less than CHF 30 million) to very 


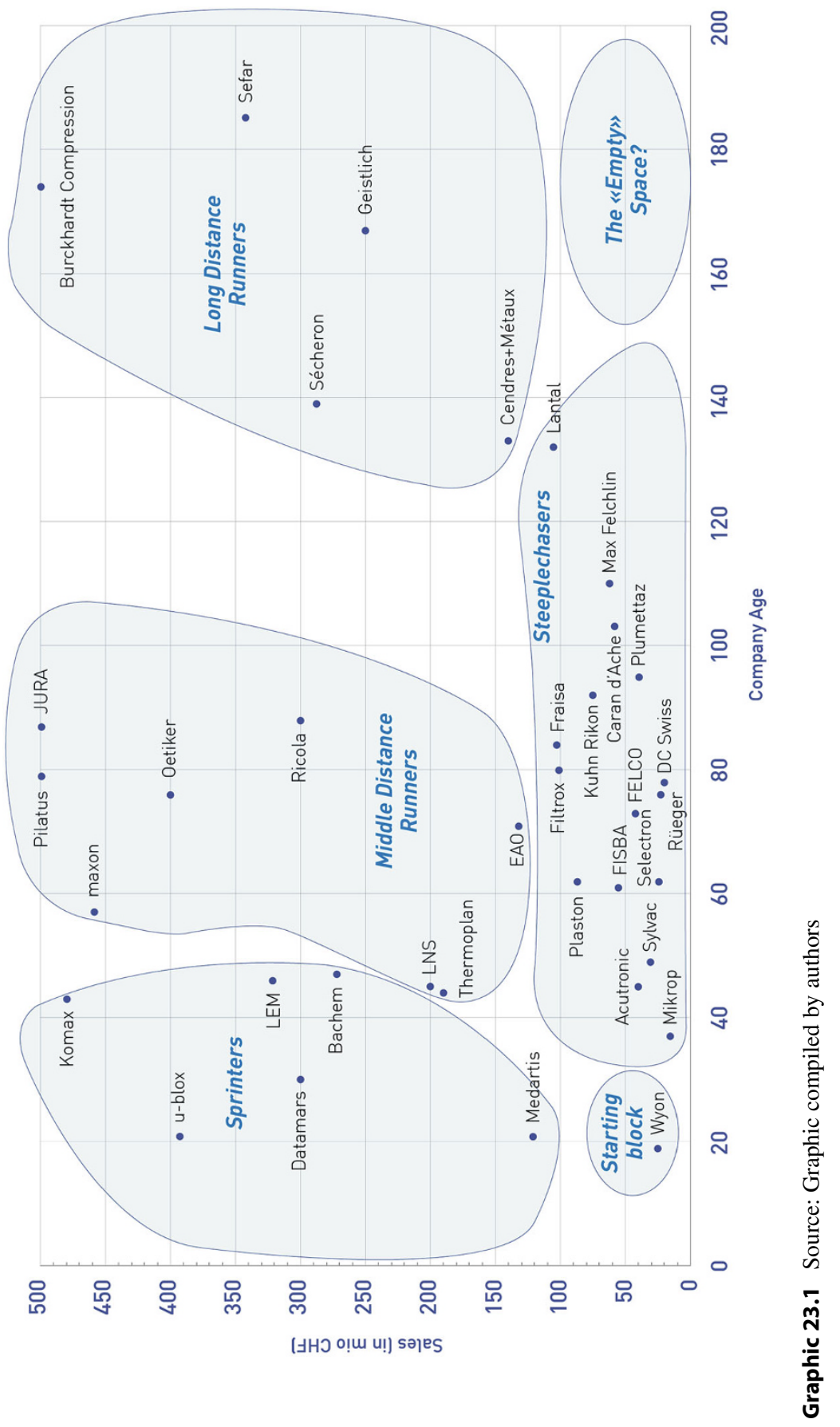


large (above CHF 300 million) was noticeable in a number of successive age decades, suggesting that firms of similar ages still displayed considerable variations in growth patterns.

Some readers might now argue that the differences lie in the nature of the industries. If we scan the companies with sales above CHF 200 million, we can see those with big-ticket items, such as Pilatus, maker of private planes, and Burckhardt Compression, maker of industrial compressors. Also, within the same size category, there are a number of industrial component producers, such as u-blox and Oetiker, selling low-ticket components, but selling large quantities of them. While the majority of larger companies operated in the B2B space, they were joined by Ricola (herbal candies) and Jura (espresso machines) targeted in the B2C space.

Since grouping companies either by age, start year, and size or by industry served did not yield consistent answers to our fundamental question about differences in growth patterns, it was concluded that insights had to come from a further analysis of strategies pursued, as well as how intensively companies adhered to those practices examined and explained in previous chapters.

\section{Clustering Companies by Development Trajectories $^{12}$}

An examination of different growth trajectories by visually grouping the companies regardless of industry and by combining them on the basis of the similarity of growth trajectories, or end destinations, yielded a number of clusters.

Six different clusters could be identified this way, based upon similarity of position on the master chart, representing different growth experiences over time. All but one of the firms were grouped into four main clusters. Two other, small clusters accounted for special circumstances. See Graphic 23.1.

Rather than simply numbering clusters one through six, illustrative labels were applied borrowed from Olympic track and field running disciplines. Olympic athletes competing in different disciplines, each of a different length, pace, or speed, are able to earn medals in any of them. This fact was attractive as an image when considering the companies covered in this research. All companies stood the test of time and survived competitive forces, and all became medalists, if not gold medal winners. But they reached that result in many different ways, choosing to compete in different disciplines.

\footnotetext{
${ }^{12}$ In Graphic 23.1, the sales scale was capped at CHF 500 mio, allowing for an expanded view of the smaller firms up to CHF 200 mio in sales. Three firms were impacted by this (Pilatus, Jura, and Burckhardt Compression). Of those, Pilatus had grown to about CHF 1 billion, and the others were slightly above the CHF 500 mio mark. Although all three firms had surpassed the originally intended cutoff of CHF 500 mio, they all spent most of their history as SMEs below that limit. Their experience and practice of how to pass the CHF 500 mio limit appeared important to the authors: company age per 2018, and sales recorded for 2017, 2018, or 2019, according to data availability.
} 


\section{Meeting the Long-Distance Runners}

The first cluster was labeled Long-Distance Runners after the Olympic 10,000 m discipline, having covered the longest distance and with a higher average age than the other SMEs researched. Located in the upper right corner of our chart, this cluster is made up by five firms (Sefar, Burckhardt Compression, Geistlich, Sécheron Groupe, and $\mathbf{C + M}$ ), all representing very different industries and yet displaying the characteristics of longevity, or stamina, combined with the significant sales growth. Averaging about 170 years of existence, these companies combined a stable governance structure with all the hallmarks of management practices, such as focus, segmentation and superior engineering and innovation.

Governance was opened up by either separating ownership from professional company management (Geistlich, Sefar, $\mathbf{C + M}$ ), turning into a public company (Burckhardt), or by installing a stable group of owners/managers (Sécheron), providing stability and allowing professional management to operate with relative independence. All but one of these companies also pursued an asset global strategy, building production assets in other parts of the world while still maintaining significant production in Switzerland. Whether public or privately held, these firms obtained access to sufficient resources to expand globally and, if needed, to make acquisitions for expansion.

\section{Meeting the Middle-Distance Runners}

In Olympic terms, Middle-Distance Runners are the athletes that compete in the $1500 \mathrm{~m}$ and $3000 \mathrm{~m}$ disciplines. These athletes combine speed with stamina for distance. The eight companies in this cluster (see Graphic 23.1) fit this description. On average, they had been in existence for about 80 years, and they have been growing to a similar size as the Long-Distance runners, but they achieved it in only half the time.

Their strategy was also characterized in terms of openness in governance, by either including independent board members (Oetiker, Ricola, Jura, EAO) or by relying on professional management (maxon, LNS, Pilatus), the latter one having achieved the largest sales volume of any firm included in this project. Importantly, none of these companies have gone public. Their solid financial performance assured them independence and considerable freedom to operate. Like many Middle-Distance Runners, they were on track to achieve longer distances over time. Some of these companies (maxon, Oetiker, LNS) built significant production assets abroad following an asset global strategy. Other firms were able to focus their business system on a reduced number of functional activities (Jura, Thermoplan), freeing capital for a market global strategy. In general, all of these companies adopted an intensive global strategy fuelling their growth. Their private and stable ownership allowed these firms to pursue long-term strategies and remain independent. 


\section{Meeting the Sprinters}

The third cluster was named Sprinters, known for speed and dominating the Olympic distances of $100 \mathrm{~m}$ or $200 \mathrm{~m}$. Sprinters display an explosive start out of the block, combined with acceleration down the stretch. Our cluster contains six firms (Medartis, u-blox, Datamars, Bachem, LEM, and Komax) that fit this characterization.

Although all of these firms have become public companies, they did so in different ways. u-blox began with external financial investors who then brought the company on the stock market, thus tapping considerable resources for growth. Komax, Bachem, and LEM undertook an IPO after several years of successful operation under their founders. Medartis waited longer for its IPO. All applied the practices of focus and product platforming. In terms of ownership structure, at u-blox, Komax, and LEM, founders no longer played a controlling role. Datamars, created as a joint venture between two firms, quickly became influenced by private equity owners who came to support an aggressive acquisition strategy that drove growth.

\section{Meeting the Steeplechasers}

For the fourth cluster, the image of the special $3000 \mathrm{~m}$ Steeple race, combining overcoming of hurdles with endurance, seemed appropriate. This cluster is made up of 16 firms in the CHF 20 million to CHF 100 million sales range and in existence for an average of 80 years. Clearly, these firms have existed for several generations, while experiencing slower growth than the other clusters. Typically, they are in sectors experiencing less underlying growth than other clusters. Included in this cluster are Mikrop, Acutronic, Sylvac, FISBA, Plaston, Filtrox, Fraisa, Caran d'Ache, Max Felchlin, Plumettaz, DC Swiss, Rüeger, Selectron, Kuhn Rikon, and Lantal Textiles.

Steeplechaser companies shared a strong preference for independence and often avoided public ownership at all costs as they saw this as a disadvantage. In line with their more limited financial resources, these firms pursued a market global strategy, investing in sales and distribution through distributors. Some companies did operate assets abroad, although they tended to be fewer and smaller than those in other clusters. M\&A transactions were infrequent.

Ownership was mostly restricted to founders or founding families or their successors. Three companies had changed hands to new family ownership (Fraisa, Acutronic, Lantal). One company was owned by a foundation (Felchlin), and two had recently been acquired by corporate owners (Selectron, Rüeger), while continuing to operate as independent entities. To make it over the long-term, these companies usually combined ownership and management into a single role. They planned to continue in that mode as long as they could bring in management that is technically sophisticated in their core business. 
The existence of a fifth cluster, which is labeled empty cluster, where long-lasting businesses below the line of CHF 120 million could be expected, suggests the difficulty of going the distance as a smaller company. The fact that several of the small companies in the cluster of Steeplechasers have slipped under different forms of corporate ownership umbrellas appears to confirm this.

\section{Who is in the Starting Blocks?}

The sixth cluster, Starting Blocks, is populated by a single firm (Wyon), the youngest company included in this project. Having passed the initial phase and entering a potential period of growth, it was not clear yet if this company will turn into a Sprinter or join the group of Steeplechasers. Judging from the experience of firms across the various clusters, Steeplechasers largely did it on their own power, such as through bootstrapping, whereas Sprinters typically opened themselves up in terms of governance, resources, and management.

The large number of start-ups emerging in Switzerland would, in the authors' view, populate the Starting Block position. The analysis presented in this book should demonstrate the options available by having outlined the long-term implications in terms of control, ownership, and freedom of operation to play a true SME game.

\section{Size vs. Longevity}

The companies included in this research have shown that they progressed along the two vectors of Size (measured in sales in CHF) versus Longevity (age of company, measured in years).

The main drivers for Longevity were more strongly correlated with the practices of focus, segmentation, and innovation, particularly when companies restricted themselves to a narrower range of activities to achieve the necessary scale through specialization. These practices were described in detail in Chapters 3 and 21. Both larger and smaller firms engaged in practices that enhanced their competitiveness, as described in Parts V and VI, thus achieving uniqueness. Smaller firms again were more reliant on the leveraging practices around Swissness, as described in Chapter 22.

The main drivers for Size were closely related to practices related to Governance Practices covered in Parts II and III. In particular, ownership structures and stability, as well as financing, provided the basis for the resources that companies could tap to fuel expansion. For the clusters of Long-Distance and Middle-Distance Runners and above all the cluster of Sprinters, access to external resources allowed the firms to engage in acquisitions, often bolting on existing businesses, expanding their production footprint and allowing them to practice a global asset strategy, all eventually leading to superior growth compared to the cluster labeled Steeplechasers. This 
practice was more pronounced for the Sprinters than for either Middle-Distance or Long-Distance Runners.

The firms that progressed diagonally, combining both sets of practices into managing for Size and Longevity, clustered among Long-Distance Runners, achieved longevity by being just as efficient in focus and segmentation as other companies and doing just as well in innovation and product building as the rest. In addition, however, they managed ownership stability issues exceptionally well by consolidating ownership into a loyal and committed group of stakeholders while tapping outside financial resources.

The cluster of Steeplechasers was further differentiated from the companies above CHF 120 million in sales from the Sprinters, Middle-Distance and LongDistance Runners through a different perspective on control. Steeplechasers were attached to ownership control to assure them operating freedom over their business. Firms belonging to other clusters, but particularly the Sprinters, traded off ownership control for access to additional resources combined with continued operating freedom, to engage fully and freely in the practices described earlier. Sprinter companies, although having largely moved from private to public ownership, had a much more positive view of their ability to maintain operating and strategic freedom of their business while under full or partial public ownership.

\section{Surviving Crises}

It would be incorrect to assume that growth of the SMEs in this study followed along a straight line. As the company profiles in the back of the book reveal, many companies had to overcome substantial adverse developments. Many of them had to conquer multiple crises. Others made courageous bets on future developments, at times even risking their business altogether. Still others fell into steep declines and had to be rescued by new owners or management.

Given that all companies were founded prior to 1999, all had to survive three recent major crises, the most recent one in the form of the global COVID-19 pandemic still ongoing as this book went to print.

- The Financial Crisis 2008 had a direct impact on a number of firms, such as Lantal Textiles through the decline in its major market for aircraft interiors, or for many smaller firms through difficulty in obtaining bank lending, with others rethinking their business strategy. Detailed stories on how this was managed can be found in the profiles of Fraisa, Rüeger, DC Swiss, Thermoplan, or Komax.

- The decision of the Swiss National Bank to stop supporting the currency relationship of the Swiss Franc versus Euro in early 2015 resulted in an immediate price increase of about 10 percent for Swiss exporters. Some companies had to find ways to deal with this, such as through different sourcing strategies or asking for support from their staff. These efforts are described in some profiles, for example, for Felco, LEM, or Sécheron. 
- Finally, as this book went to print, all companies found themselves in the midst of the economic impact due to the global COVID-19 Pandemic that began in early 2020. Since the company profiles and documentation were concluded by the end of 2019, the decision was taken not to reinterview all firms on how they were dealing with the impact of the pandemic. Past history would suggest, however, that these companies having stood the test of time will, by and large, also master this crisis, although the lasting impact might well leave bigger scars in their industrial fabric than the previous two crises of 2008 and 2015.

Although the most recent crises are more likely to be remembered by our readers, there were major wars that shaped the economic environment in some very restrictive ways and were often of longer duration than the more recent crises, however impactful they might have been.

- World War I (1914-1918) was experienced by eight of the firms, all founded still in the nineteenth Century, resulting in loss of market access or difficulty in sourcing materials for production. The profiles of Felchlin and Caran d'Ache touch on the impact on those companies.

- The Great Depression of the 1930s was experienced by 14 of the firms, at times requiring adaptations due to loss of customers (Plumettaz). Despite the difficult economic circumstances at that time, three companies were founded (Ricola, Jura, Fraisa), thriving and growing to this day.

- The period of World War II (1939-1945) was particularly difficult for any exportoriented firm because all borders around Switzerland closed, export markets were lost, and companies had to retrench to the Swiss market. The market closure gave the impetus for founding Pilatus and Filtrox, and three more entrepreneurs saw an opportunity to open up during the war (DC Swiss, Oetiker, Rüeger).

- The post-World War II period was a time of rapid and sustained economic growth that benefited the exporting SMEs in particular. Several firms were founded during this period, a boom ending with the Oil Crisis 1973. By the end of this period, all but five of the 36 companies were operating.

Reflecting on the experience of these firms over decades indicates that they were not simply one-hit wonders or flash-in-the-pans but represented sustained practices over time. It can therefore be claimed that the practices described in this book have stood the test of time. Of course, it is also true that many firms were not able to make it through such upheavals, but the focus here is on the survivors.

\section{Courageous Bets for Growth}

A number of our companies wagered significant bets on new markets, technologies, or processes that had to be considered daring in relation to the size of the companies. These are not the initial investments, or risks, assumed by the company founders, or 
investments made in the course of company expansions. Instead, the bets referred to here are later investments with a substantial impact on the trajectory of a company.

The most significant was the decision by Pilatus Aircraft to invest a sum estimated to have been about CHF 500 million for the development of a new executive jet, PC-24, with the effect of eventually doubling the company's business. This choice, requiring investments over many years with an uncertain outcome, was certainly courageous. ${ }^{13}$

Other companies who entered into major investments changing the course for their business are included below.

- Thermoplan, investing a significant amount of the founder's savings at that time into a fully automatic coffee machine for use in hospitality.

- Datamars, taking up new capital to expand into the veterinary segment for its identification business.

- Jura, ceasing its production of household and kitchen appliances to invest in a fully automatic espresso machine for in-home use.

- Geistlich, leaving the old-fashioned bone processing business to invest in natural bone enhancement material for dental surgeries.

- Lantal, making significant investments and acquiring capacity to produce materials for passenger aircraft and ground transport interiors.

- Selectron, placing significant investments into the development of in-train electronic controls.

- EAO, stepping out of the transformer business and investing all of its resources to build the pushbutton business.

The full stories behind these investments are contained in the company profiles of each firm.

\section{Resurrected Companies}

A final mention is earned by a few companies that were saved from certain decline and resurrected by new owners or management, making the companies blossom again, often reaching new heights. In the company profiles, close attention was paid to these ups and downs, and the resurrection of two companies are detailed-these firms would almost certainly have disappeared without the intervention of new ownership.

- Selectron, targeted for shutdown by its owner Schneider Group, who had acquired the unwanted business in the course of a number of acquisitions, was resurrected by new management when entering the in-train electronic control

\footnotetext{
${ }^{13}$ For more details of this investment, see Pilatus company profile.
} 
business and growing to five times the size over about 20 years, with a significant share in its sector.

- Sécheron, where the new owner-management group that assumed its assets from a financial owner, together with adept management, returned the company to its traditional position as a major player in energy management for electric-powered trains.

The research also uncovered other histories of resurrected companies in the Swiss SME space, although these firms could not be interviewed.

It is important to mention DT Swiss in this context, maker of bicycle spokes and wheels, resurrected out of the terminated operation of DT (Tréfilerie de Bienne), an old wire and cable manufacturer formed in 1634. The company, employing almost 1000 in 1975, went into decline resulting in liquidation in 1994. Three managers, capitalizing on the company's specialty for cold wire extrusion, spun out the core of the new business on spokes, now exceeding CHF 100 million in sales, with about 450 employees (2015) and achieving global leadership in offtrack bicycle wheels.

A second company to be mentioned here is Dottikon Exclusive Synthesis, a specialist in hazardous chemical reactions performed for other companies. This business, originally founded in 1913 as an explosives company, evolved over many years to become a producer of chemical intermediates. Acquired in 1987 by Ems-Chemie, the business was spun off in 2005 and went public, growing ever since into a freestanding business with sales of about CHF 175 million (2019-2020).

The inclusion of the histories of both Dottikon and DT Swiss as part of this review, in conjunction with the experience of Selectron and Sécheron, signals an important message when reviewing the trajectories of the researched SMEs: Any SME, over its lifetime, may encounter a negative patch. Given the tenacity of a new management, or new owners, a company's fortune may be turned around, usually when it relies on the firm's traditional strength, thus extending the life of the business. When this occurs, new management and owners depend on the same principles detailed in the analysis of this book.

SMEs, if well cared for and managed, have many lives!

Open Access This chapter is licensed under the terms of the Creative Commons Attribution 4.0 International License (http://creativecommons.org/licenses/by/4.0/), which permits use, sharing, adaptation, distribution and reproduction in any medium or format, as long as you give appropriate credit to the original author(s) and the source, provide a link to the Creative Commons license and indicate if changes were made.

The images or other third party material in this chapter are included in the chapter's Creative Commons license, unless indicated otherwise in a credit line to the material. If material is not included in the chapter's Creative Commons license and your intended use is not permitted by statutory regulation or exceeds the permitted use, you will need to obtain permission directly from the copyright holder.

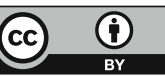

